\title{
EXTRUSION OF THE ARCHAEAN UAUÁ BLOCK IN THE NORTHERN SEGMENT OF THE ITABUNA-SALVADOR-CURACCÁ OROGEN, BAHIA, AND IMPLICATIONS FOR DIAMOND PROSPECTING
}

\author{
ELSON P. OLIVEIRA, MARCELO J. CARVALHO \& MARIA IRIAN M. DUARTE
}

Orogen-parallel displacement of large-scale tectonic blocks is a common feature of several orogenic belts (e.g. the Himalayas). The phenomenon is generally known as extrusion tectonics and occurs in response to stress accommodation after plate collision. Displacement of blocks or terranes takes place along high-angle shear zones that may have their roots propagated down into the lithospheric mantle, provided a rigid, coupled crust-mantle system is formed, such as in Archaean cratons and nucleii. If the minimal conditions for partial melting of the mantle are attained, then diamond-rich magmas (kimberlite, lamproite and lamprophyre) may rise along or near the shear zones and be emplaced at shallow levels in the crust.

The Palaeoproterozoic Itabuna-Salvador-Curaçá orogen, Bahia, is a collisional orogen (cf. Windley 1995) that formed by frontal or oblique collision of two continents during the Transamazonian orogeny. At the latitude of Salvador, this orogenic belt can be separated into the northern and southern segments. Detailed description about the latter is given in Barbosa $(1990,1997)$.

The northern segment of the Itabuna-Salvador-Curaçá orogen (Fig. 1), the main subject of this communication, is thought to have originated by collision of two Archaean blocks, namely the Lençois block to the west and the Serrinha nucleus to the east. The latter comprises migmatites and gneisses of the Santa Luz complex overlain by metamorphosed sedimentary and volcanic rocks of the Rio Itapicuru greenstone belt (RIGB), later intruded by several types of granites and syenite. Although the Serrinha nucleus and RIGB have been severely deformed during the Transamazonian orogeny, two less deformed blocks are recognized, i.e. the Retirolândia block to the south and the Uauá block to the north.

According to Chauvet et al. (1997) RIGB underwent two deformation events. The older of compressive nature during the closure of the sedimentary-volcanic basin, and the later of $\mathrm{N}$-S-trending strike-slip nature. During the latter event, intrusion of lamprophyre dykes occurred in the Maria Preta gold deposit, and possibly also of small kimberlite bodies, close to the Queimadas town to the north.

Farther north, the Uauá Block (3.16-2,93 Ga, Oliveira et al. 1999) displays a general sigmoid shape and lies in contact by shear zones with the Paleoproteorozoic Rio Capim metasedimentary-volcanic sequence to the east and the quartzite-gneiss Caldeirão belt to the west. The Uauá block consists of mafic-ultramafic complexes, high-grade gneiss and granitoids intruded by at least two mafic dyke swarms. Several diamondiferous kimberlite bodies occur along or near the contact between the Uauá block and the Rio Capim Sequence.

Field evidence for movement of the Uauá Block moved from south to north is the regional distribution of the youngest mafic dyke swarm referred to above and kynematic indicators along the boundary between the Uauá Block and the Rio Capim sequence. Thus, in the central region of the Uauá Block, dykes of the latter swarm trend mostly to NE-SW. Apart from minor faults and occasional sheared margins these dykes are not significantly deformed. However, towards the western edge of the Uauá Block, the dykes gradually change direction from NE-SW through N-S to NW-SE until they become parallel to the Caldeirão Belt and disappear. Some of these dykes can be traced within the transition to the Caldeirão Belt where they are strongly disrupted or boudinaged. Metamorphic titanite grains from one of these dykes yielded the age of 2,039 Ma (Oliveira et al. 2000). The observed change of dyke direction within the Uauá Block is interpreted as large-scale drag folds, indicating a left-lateral displacement of the Uauá Block in relation to the Caldeirão Belt. On the other hand, the contact between the Palaeoproterozoic Rio Capim sequence and the Archaean Uauá Block is made through the sub-vertical Galo do Ouro shear zone (Souza, 1986). According to Jardim de Sá et al. (1984) and Souza (1986) this 20-500 m-wide shear zone had a complex structural evolution and comprises high-grade mylonites with dominantly sub-horizontal mineral stretching lineation. Petrofabric studies of quartz c-axis carried out by Souza (1986), coupled with kynematic indicators observed by this author, Jardim de Sá et al. (1984) and ourselves, such as syn-mylonitic asymmetric folds, S-C relations and mica-fish support a right-lateral kynematics for the Galo do Ouro shear zone. Sheared mafic dykes of the Uauá Block close to this shear zone yielded a K-Ar age of ca. 2.0 Ga (Bastos Leal et al. 1994). All the structural and geochronological data corroborate the synchronous reworking of both western and eastern margins of the Uauá Block and its displacement from south to north.

Although the precise age of diamond-bearing bodies along the contact of the Uauá Block and the Rio Capim sequence as well as on the western margin of the Rio Itapicuru greenstone belt is not fully constrained, is possible that their emplacement was controlled by continental-scale shear zones developed during orogen-parallel displacement of blocks, such as the Archaean Uauá block, or later. Areas close to these shear zones 
may thus be interesting targets for diamond exploration.

Acknowledgments The authors greatly acknowledge to two anonymous referees of RBG for useful comments and suggestions. The Brazilian FAPESP (99/05760-4) and CNPq (300845/91-0) are grateful for the research grants to EPO, and CAPES for a graduate grant to MIMD. To reviewers of RGB for suggestions to the original.

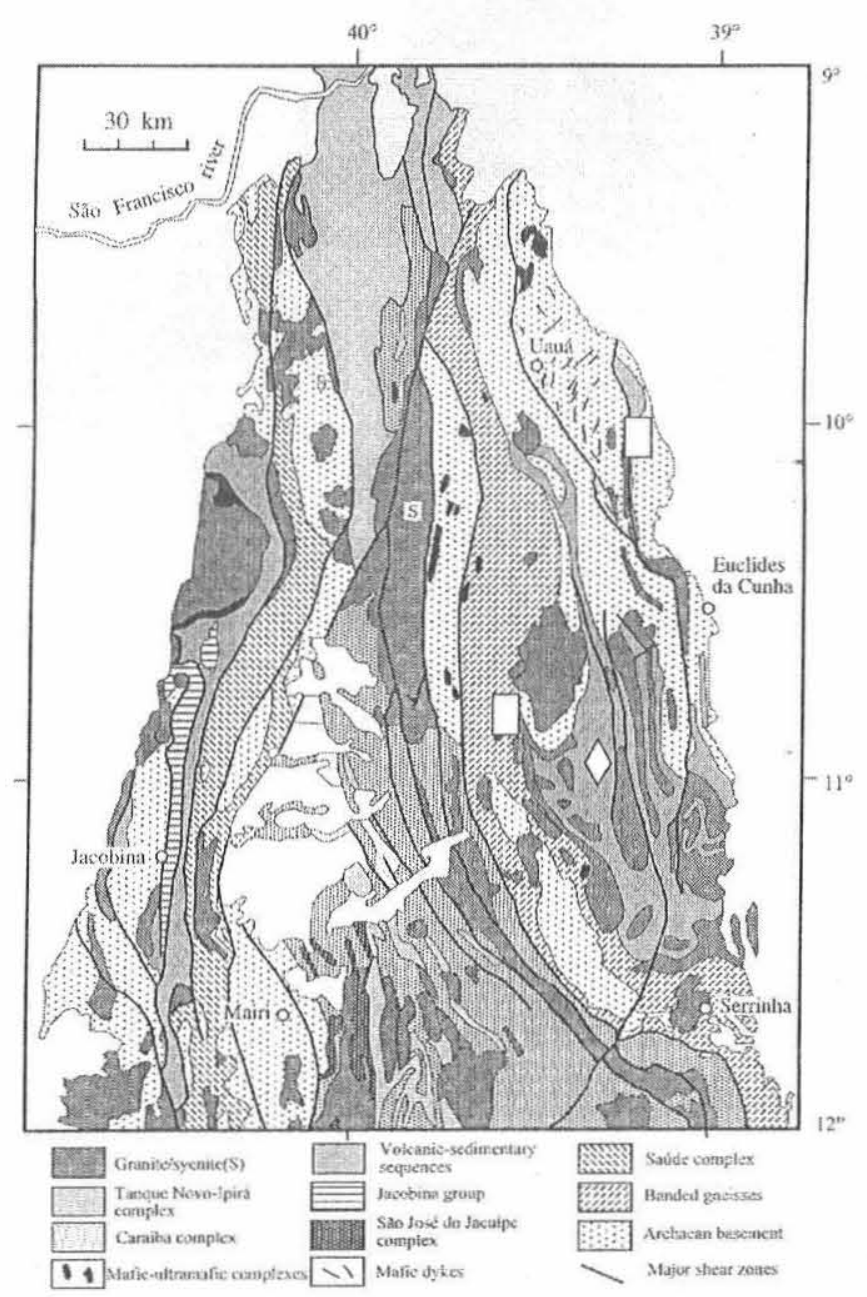

Figure 1: Location of kimberlite ( ) and lamprophyre bodies ( ) in the eastern half of the northern segment of the Itabuna-Salvador-Curaçá orogen. Geology modified after Kosin et al. (in press).

\section{References}

Barbosa J.S.F. 1990. The granulites of the Jequié Complex and Atlantic Mobile Belt, southern Bahia, Brazil - An expression of Archean-Proterozoic plate convergence. In: D. Vielzeuf and P. Vidal (eds.) Granulites and Crustal Evolution. Springer Verlag, pp. 195-221.

Barbosa J.S.F. 1997. Síntese do conhecimento sobre a evolução geotectônica das rochas metamórficas arqueanas e paleoproterozóicas do embasamento do Craton do São Francisco na Bahia. Revista Brasileira de Geociências, 27:241-256

Bastos Leal L.R., Teixeira W., Piccirillo E.M., Menezes Leal A.B., Girardi V.A.V. 1994. Geocronologia Rb/Sr e K/Ar do enxame de diques máficos de Uauá, Bahia (Brasil). Geochimica Brasiliensis, 8:99-114.

Chauvet A., Silva F.C.A., Faure M., Guerrot C. 1997. Structural evolution of the Paleoproterozoic Rio Itapicuru granite-greenstone belt (Bahia, Brazil): the role of synkinematic plutons in the regional tectonics. Precambrian Research, 84:139-162.

Jardim de Sá E.F.J., Souza Z.S., Fonseca V.P., Legrand J.M. 1984. Relações entre "greenstone belts" e terrenos de alto grau: o caso da Faixa Rio Capim, NE da Bahia. In: SBG, XXXIII Congr. Bras. Geol., Rio de Janeiro, Anais: 2615-2629.
Kosin M. Guimarães J.T., Abram M.B. Folha Aracaju-SW, folha SC.24-Y. Serviço Geológico do Brasil (CPRM). Programa Levantamentos Geológicos Básicos do Brasil (in the press).

Oliveira E.P., Lafon J-M., Souza Z.S., 1999. Archaean-Proterozoic transition in the Uauá Block, NE São Francisco Craton, Brazil: U-Pb, Pb-Pb and $\mathrm{Nd}$ isotope constraints. In: SBG, VII SNET, Anais, Sessão 1, pp. 41-43.

Oliveira E.P., Souza Z.S., Corrêa Gomes L.C. 2000. U-Pb dating of deformed mafic dyke and host gneiss: implications for understanding reworking processes on the western margin of the Archaean Uau- Block, NE São Francisco Craton, Brazil. Revista Brasileira de Geociências, 30:149-152.

Souza Z.S. 1986. Zonas de cisalhamento no greenstone belt do Rio Capim, NE da Bahia - Um modelo de deformação progressiva. In: SBG, Congr. Bras. Geol., 34, Goiânia, Anais. Vol. 2:678-694.

Windley B.F. 1995. The evolving continents. 3rd ed. John Wiley and Sons Ltd.

Manuscrito NB-032

Recebido em 18 de novembro de 2001 Revisão dos autores em 15 de dezembro de 2001 Revisão aceita em 17 de dezembro de 2001 